\title{
Acute rejection and graft survival in renal transplanted patients with viral diseases
}

\author{
Francesca B Aiello ${ }^{1, *}$, Fiorella Calabrese ${ }^{2}$, Paolo Rigotti ${ }^{3}$, Lucrezia Furian ${ }^{3}$, Stefano \\ Marino $^{4}$, Riccardo Cusinato ${ }^{5}$ and Marialuisa Valente ${ }^{2}$ \\ ${ }^{1}$ Department of Oncology and Neuroscience, University of Chieti, Chieti, Italy; ${ }^{2}$ Institute of Pathological \\ Anatomy; ${ }^{3}$ Department of Medical and Surgical Sciences, University of Padua, Medical School, Padua, Italy; \\ ${ }^{4}$ Azienda Ospedaliera, Venice, Italy and ${ }^{5}$ Microbiology, Azienda Ospedaliera, Padua, Italy
}

\begin{abstract}
Transplanted patients are susceptible to viral infections; thus, the aim of this study was to evaluate the features of acute rejections and the outcome of the renal graft in transplanted patients with herpes virus diseases. Renal biopsies from 30 renal transplanted patients undergoing early acute rejection (type IA and IB according to the Banff 97 classification) were evaluated. In total, 15 of these patients experienced cytomegalovirus (CMV) or Epstein-Barr virus disease within the first year following transplantation (group I) and 15 patients showed no evidence of viral infection (group II). No significant differences between the groups in terms of age, male/female ratio, living/cadaveric donor ratio, cold ischemia time, HLA A-B matching, pretransplant panel reactive antibody test, occurrence of post-transplant tubular necrosis, plasma levels of cyclosporin A and mean percent increase of serum creatinine at the time of the biopsy were observed. In group I biopsies, the mean number of interstitial plasma cells, as well as the mean number of CD79a-positive cells (B lymphocytes and plasma cells) was significantly higher than in group II $(P<0.01$ and $<0.01$, respectively). There was a positive correlation between the number of infections and the number of plasma cells $(P<0.05)$. In transplanted patients, CMV can trigger the formation of anti-endothelial cell antibodies, which have been proposed to play a role in antibody-mediated rejections. We investigated whether a deposition of C4d, a marker of antibody-mediated reactions, was present in renal peritubular capillaries. In group I C4d deposition was found in five cases, while in group II it was not observed $(P<0.05)$. In group I, 7/15 patients developed chronic allograft nephropathy vs $1 / 15$ patients in group II $(P<0.05)$. The estimated 1-, 5- and 8-year cumulative graft survival rates were 80,66 and $57 \%$, respectively, in group I, while in group II the estimated 8-year cumulative survival rate was $100 \%(P<0.05)$. In conclusion, acute rejection biopsies of patients with viral infections displayed plasma cell infiltrates and, in several cases, C4d deposition. Our study suggests a role of B lymphocytes in the pathology of these rejections and confirms the association between viral infections and poor graft survival.
\end{abstract}

Modern Pathology (2004) 17, 189-196, advance online publication, 5 December 2003; doi:10.1038/modpathol.3800033

Keywords: rejection; CMV; EBV; plasma cells; C4d; graft survival

Transplanted patients submitted to immunosuppressive therapy that profoundly impairs $\mathrm{T}$ lymphocyte function, are particularly susceptible to diseases caused by herpes viruses such as cytomegalovirus (CMV) and Epstein-Barr virus (EBV). ${ }^{1}$ Active CMV infection is the most frequent infection in renal transplanted patients, ${ }^{2,3}$ and it has been shown to be a risk factor for the occurrence of acute rejection episodes. $^{4-9}$ CMV infection induces activation and proliferation of $\mathrm{B}$ lymphocytes in mice as in

Correspondence: M Valente, Institute of Pathological Anatomy, University of Padua, Medical School, Via A Gabelli, 61, Padova 35121, Italy.

E-mail: marialuisa.valente@unipd.it

*Visiting Professor at the University of Padua, Padua, Italy.

Received 22 April 2003; revised 24 September 2003; accepted 14

October 2003; published online 5 December 2003 humans. ${ }^{10,11}$ In renal transplanted patients experiencing CMV infection, an early transient increase in peripheral B lymphocyte levels has been documented. ${ }^{12}$ Active EBV infection occurs in approximately $30 \%$ of renal transplanted patients, ${ }^{2,13}$ and is also associated with B lymphocyte activation and proliferation. EBV exhibits tropism for B lymphocytes ${ }^{14}$ and causes expansion of the infected lymphocytes, which is usually self-limiting. The symptoms of EBV infection are nonspecific; ${ }^{1}$ however, in $1 \%$ of renal transplanted patients, EBV infection results in a post-transplantation lymphoproliferative disorder (PTLD). ${ }^{15}$ Interestingly, an association between EBV infection and the occurrence of late acute rejection episodes has recently been reported in renal transplanted patients. ${ }^{16}$ In heart transplantation, it has been clearly demonstrated that viral infections significantly increase the risk of developing chronic 
graft failure. ${ }^{17-21}$ In renal transplantation, there are data suggesting that CMV infection increases the risk of developing chronic allograft nephropathy in rats $^{22,23}$ and in humans. ${ }^{24,25}$ It has been shown that CMV triggers the formation of various autoantibodies in bone marrow transplanted patients. In particular, the presence of an antibody recognizing the cell surface protein CD13, present on all CMV susceptible cells, is associated with the development of chronic graft $v s$ host disease. ${ }^{26-29}$ In $80 \%$ of renal and heart and in $43 \%$ of liver transplanted patients who had CMV infections, high levels of anti-endothelial cell antibodies have been demonstrated. ${ }^{30-32}$ A number of studies suggests that these antibodies play an important role in the development of antibody-mediated rejection. ${ }^{3-37}$ Antibody-mediated rejection has a poorer prognosis than cellular rejection and needs a more aggressive and targeted antirejection therapy. ${ }^{38,39}$ It can be a component of acute rejection in renal transplantation in up to $30 \%$ of the cases, and is not restricted to presensitized patients. ${ }^{40-42}$ Histological features suggesting an antibody-mediated injury (presence of neutrophils in glomerular and peritubular capillaries, neutrophilic tubulitis and fibrinoid necrosis of glomerular capillaries and arteries) are absent in $15 \%$ of the cases. ${ }^{42}$ In addition, the histology of this type of rejection can be misleading. ${ }^{40}$ The deposition of $\mathrm{C} 4 \mathrm{~d}$, the cleavage product of the complement component $\mathrm{C} 4$ in the peritubular capillaries of the graft, is considered a good marker of an antibody-mediated injury and an important diagnostic criterion. Whether some acute rejections in renal transplanted patients who experience viral infections have an antibody-mediated component has not been investigated. The aim of this study was to evaluate the pathological characteristics of acute rejection and the graft survival in renal transplanted patients affected by one or more active CMV or EBV infection during the year of the rejection.

\section{Materials and methods}

\section{Patients}

Clinical and laboratory records of renal transplanted patients undergoing biopsy for acute rejection between 1989 and 1999 were reviewed. The biopsies of 15 patients (eight males and seven females, mean age: $38.1 \pm 10.1$ years) with one or more active, symptomatic CMV or EBV infection within the first year following transplantation (ie, year of the biopsy) (group I) and the biopsies of 15 patients (11 males and four females, mean age: $37.4 \pm 13.0$ years) without any clinical or laboratory evidence of viral infection within the first year following transplantation (ie, year of the biopsy) (group II) were selected. Pretransplant cytotoxic crossmatch was negative in each case. Pretransplant detection of panel reactive circulating antibodies (PRA test) $\leqslant 5 \%$ was considered negative, a PRA test $\geqslant 30 \%$ was considered positive. The rejections were matched as closely as possible for type and grade according to the Banff 97 classification, ${ }^{43}$ all occurred within the first 6 months after transplantation, and were the first rejection episode. The mean percent increase in serum creatinine from the baseline level was $23 \%$. In group I, 14 rejections were treated with methylprednisolone pulses, one was steroid resistant, and OKT3 was administered. In group II, 13 rejections were treated with methylprednisolone pulses, two were steroid resistant, and OKT3 was administered. In group I, 12 grafts were from cadaver donors and three from living donors; results of the pretransplant PRA test were positive in one patient and negative in 14. The protocol for immunosuppression was based on cyclosporin in 13 cases and on FK506 in 2. In group II, 13 grafts were from cadaver donors and two from living donors; results of the pretransplant PRA test were positive in two patients, negative in 12 and not available in one. The protocol for immunosuppression was based on cyclosporin in 11 cases and on FK506 in four.

\section{Diagnostic Criteria for CMV and EBV Diseases}

After transplantation, all patients were monitored every week CMV, HSV, VZV, EBV, by serological analyses (EIA for CMV, HSV and VZV IgM and IgG, IF for EBV-CA IgM and IgG, EBV-EA IgG and EBVNA IgG) until discharged from the hospital. CMV infections in the blood, sputum, and urine were also monitored every week: the viral nuclear antigen pp65 in blood polymorphonuclear granulocytes was identified by immunofluorescence (antigenemia). ${ }^{44}$ The viral nuclear antigen pp72 was identified by immunofluorescence in mink lung epithelial cells infected with urine or sputum samples (Shellvials). ${ }^{45}$ After discharge, for the first year after transplantation serological analyses for EBV infection, and CMV antigenemia, viruria and examination of sputum samples were performed every month. In group I, all infections were clinically apparent: the diagnosis of CMV disease was made in 13 cases when clinical symptoms of the disease were associated to one or more positive cultures from blood, urine or sputum samples. The diagnosis of EBV disease was made in two cases when clinical symptoms of the disease were associated with the detection of IgG to EBV early antigen (EA) and with a four-fold or greater rise in the titer of IgG to viral capsid antigen (VCA). ${ }^{46}$

\section{Histopathology}

Serial sections were prepared from renal biopsies. Biopsies were considered adequate when at least 10 glomeruli and two arteries were present according to the Banff 97 classification. ${ }^{43}$ Hematoxylin-eosin, PAS, Heidenhain trichrome and Weigert Van Gieson 
stains were performed. Plasma cells were counted in 20 randomly selected high-power fields on hematoxylin-eosin-stained sections. For immunohistochemistry, sections were stained by the Envision technique (Dako, Glostrup, Denmark) after microwave antigen retrieval using the monoclonal antibodies anti-CD79a (Immunotech, Marseille, France), anti-CMV clone CCH2 (Dako, Glostrup, Denmark) and anti-CMV MAB810 (Chemicon, Temecula, CA, USA). CD79a + cells were counted in 20 randomly selected high-power fields on hematoxylin counterstained sections. The anti-CMV antibody clone CCH2 reacts with a nuclear early antigen and a nuclear and cytoplasmic late antigen. The anti-CMV MAB810 antibody reacts with a nuclear immediate early antigen that is detected throughout the complete infection cycle. For detection of C4d, paraffin sections were stained by an indirect immunoperoxidase technique after antigen retrieval by pressure-cooking using a polyclonal anti-C4d antibody (Biomedica, Vienna, Austria). Positive as well as negative control sections were included in each test series. In negative control sections, primary antibodies were replaced by irrelevant matched monoclonal antibodies or nonimmune serum as appropriate. Renal biopsies from nontransplanted patients (with unrelated pathologies) were also used as negative controls. Sections showing chronic gastritis, CMV pneumonia, and acute humoral rejection were used as positive controls for CD79a, CMV and C4d stainings, respectively. All sections were examined by two pathologists.

\section{In Situ Hybridization for EBV}

In situ hybridization for EBV encoded small RNA (EBER) was performed on paraffin sections using the fluorescein-conjugated EBER oligonucleotide probe (Biogenex, San Ramon, CA, USA)

\section{Statistical Analysis}

Results are expressed as mean \pm s.d. The $\chi^{2}$ Fisher test, Student's $t$-test for nonpaired data and Spearman's correlation test were performed for statistical analysis. Graft survival was calculated by using the method of Kaplan-Meier. The Wilcoxon test was used to assess the statistical significance of the differences in survival.

\section{Results}

\section{Histopathological Evaluation of Renal Biopsies}

Renal biopsies from 30 renal transplanted patients undergoing acute rejection were evaluated according to the Banff 97 classification. In all, 15 of these patients experienced CMV or EBV disease at least once within the first year following transplantation (group I). The remaining 15 patients showed neither clinical nor laboratory signs of CMV or EBV disease within the first year following transplantation (group II). In group I, eight rejections were type IA (cases 2, 4, 5, 8, 11, 13, 14, 15) and seven were type IB (cases 1, 3, 6, 7, 9, 10, 12) (Figure 1a). In group II, 10 rejections were type IA (cases $2,3,6,8,9,11,12$, $13,14,15$ ) and 5 were type IB (cases $1,4,5,7,10$ ). In neither group did biopsies show intimal arteritis. In the majority of the patients of group I, a conspicuous plasma cell infiltrate was present in the interstitium (Figure 1b). The mean number of plasma cells/20 fields in group I $(170 \pm 110)$ was significantly higher than that observed in group II $(19 \pm 9)(P<0.01)$. The number and the distribution of plasma cells/20 fields observed in all patients are shown in Figure 2. Immunohistochemical staining confirmed that numerous cells were positive for CD79a, a marker specific for plasma cells and B lymphocytes (Figure 1c). The number of CD79a + cells $/ 20$ fields in group I $(451 \pm 332)$ was significantly higher than that observed in group II $(60 \pm 37)(P<0.01)$. In 14 cases in group I and 14 cases in group II, immunohistochemical staining with anti-C4d antibody was performed. Only a diffuse and bright staining of peritubular capillaries was considered positive (Figure 1d). In group I, five cases were positive while no positive cases were present in group II $(P<0.05)$. In 11 cases of group I and in 11 cases of group II, immunohistochemical staining with two anti-CMV antibodies (one recognizes a nuclear early antigen and cytoplasmic late antigen and the other recognizes a nuclear immediate early antigen detected throughout the complete infection cycle) and in situ hybridization for EBV EBER were performed on the renal tissue samples. All cases resulted negative. In group I laboratory analyses for the demonstration of CMV or EBV infection, performed at the time of the rejection biopsy, resulted negative in 12 cases. In three cases, the laboratory tests for viral infection were positive. The rejection biopsies preceded the occurrence of the viral disease in four cases (range 20-54 days) and followed it in eight (range 40-309 days).

\section{Evaluation of CMV and EBV Disease in the Patients of Group I}

In group I, the diagnosis of CMV disease was made in 13 patients when symptoms of the disease were clinically apparent and one or more cultures from blood, urine or sputum samples were positive. The characteristics of these infections (number of infections, positive samples and antigenemia values) are shown in Table 1. Only one infection was primary (case 6). Six patients experienced multiple infections; in all cases prolonged fever was present. In some cases, an increased level of serum creatinine, a slight elevation of hepatic enzymes and moderate leukopenia were present. In one patient the disease, evident 73 days after the occurrence of acute 
192
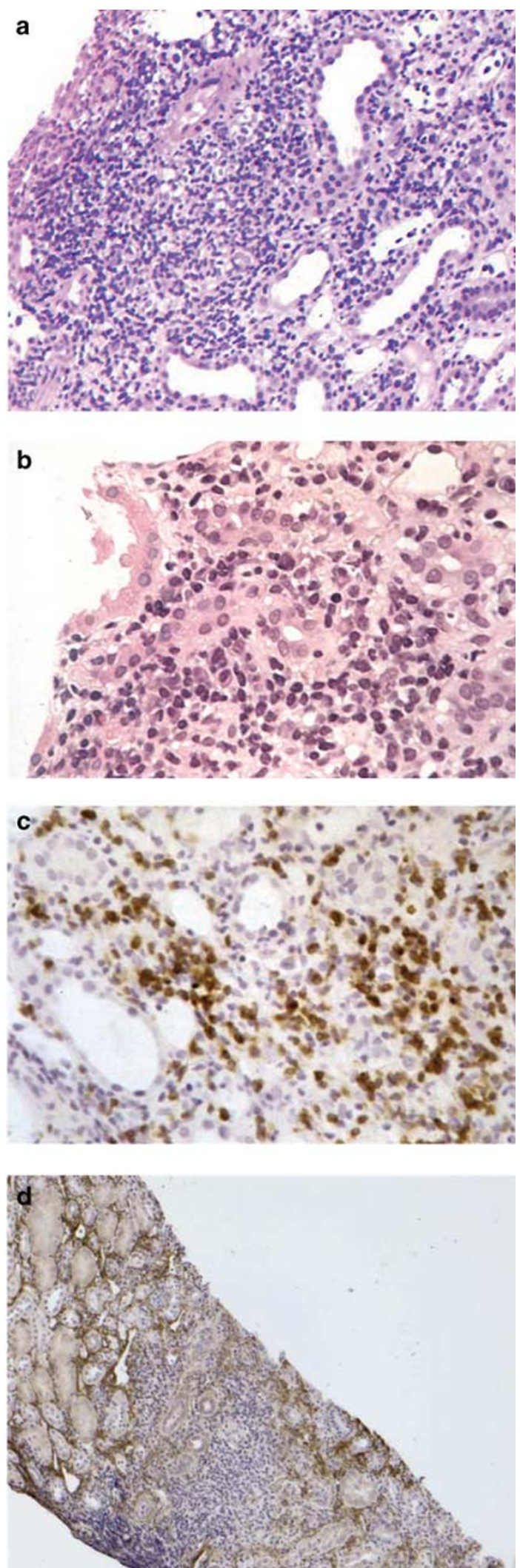

Figure 1 Renal biopsy: (a) microscopic appearance of acute tubulointerstitial rejection (case 10) PAS stain (original magnification $\times 40$ ); (b) plasma cell infiltrate (case 10) (original magnification $\times 80$ ); (c) CD79a-positive cells (case 10) (original magnification $\times 80$ ); (d) C4d deposition in peritubular capillaries (case 2) (original magnification $\times 80$ ).

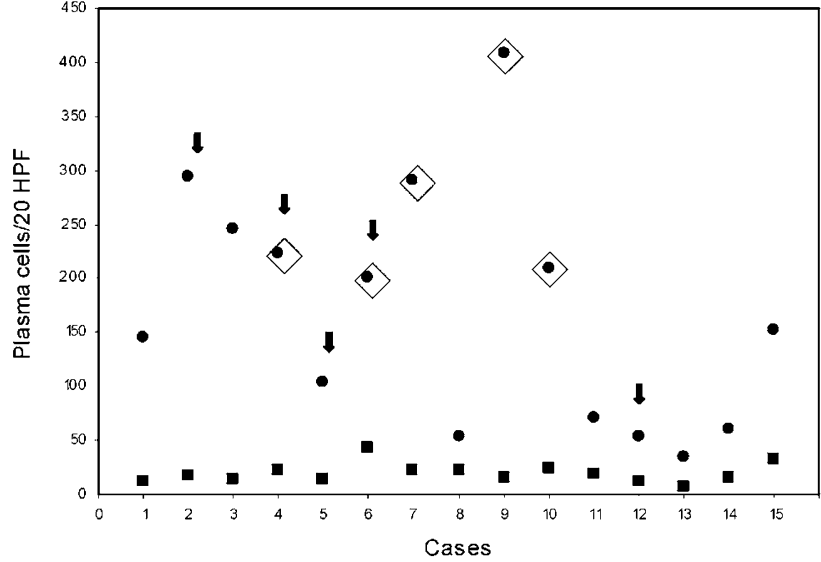

Figure 2 Distribution of plasma cells in group I (circles) and in group 2 (squares) cases. The mean number of plasma cells/20 fields in group I $(170 \pm 110)$ was significantly higher than that observed in group II $(19 \pm 9)(P<0.01)$. Cases 2 and 5 correspond to patients with EBV infection. Closed circles corresponding to patients with two or more CMV infections, and to patients with C4d-positive staining are highlighted with open diamonds and with arrows, respectively.

Table 1 Characteristics of CMV infections

\begin{tabular}{|c|c|c|c|c|c|c|c|}
\hline \multirow[t]{2}{*}{ Case } & \multirow[t]{2}{*}{ Infections } & \multicolumn{3}{|c|}{ Positive samples } & \multicolumn{3}{|c|}{ Antigenemia ${ }^{\mathrm{b}}$} \\
\hline & & 1 & 2 & 3 & 1 & 2 & 3 \\
\hline 1 & 1 & $\mathrm{u}$ & & & & & \\
\hline 3 & 1 & $\mathrm{u}$ & & & & & \\
\hline 4 & 2 & $\mathrm{u}, \mathrm{s}$ & $\mathrm{u}, \mathrm{s}$ & & & & \\
\hline 6 & 3 & $\mathrm{~b}, \mathrm{~s}, \mathrm{u}$ & $\mathrm{b}$ & b,s & 150 & 110 & 75 \\
\hline 7 & 2 & $\mathrm{~s}$ & $\mathrm{~s}$ & & & & \\
\hline 8 & 1 & $\mathrm{~b}, \mathrm{~s}$ & & & 1000 & & \\
\hline 9 & 3 & $\mathrm{~b}$ & $\mathrm{~b}, \mathrm{~s}, \mathrm{u}$ & $\mathrm{b}$ & 7 & 350 & 18 \\
\hline 10 & 2 & $b$ & $\mathrm{~b}$ & & 350 & 72 & \\
\hline 11 & 1 & $\mathrm{~b}$ & & & 110 & & \\
\hline 12 & 1 & $\mathrm{~b}$ & & & 75 & & \\
\hline 13 & 1 & $\mathrm{~b}$ & & & 500 & & \\
\hline 14 & 1 & $\mathrm{~b}$ & & & 1000 & & \\
\hline 15 & 1 & $\mathrm{~b}$ & & & 1000 & & \\
\hline
\end{tabular}

b, blood; s, sputum; u, urine.

Number of p65 positive cells per 200000 leukocytes.

rejection, was severe. Fever and high antigenemia levels were associated with severe leukopenia and high levels of serum creatinine. Immunosuppressive therapy was withdrawn and the patient developed vascular acute rejection followed by graft loss. The diagnosis of EBV disease was made in patients 2 and 5 . These patients experienced prolonged fever and an increase in serum creatinine levels associated with serological signs of EBV reactivation.

Interestingly, we found a positive correlation between the number of infections occurring within the first year following transplantation (ie, year of the biopsy) and the number of plasma cells present in the biopsy of the rejections (Spearman's correlation test, $r=0.6, P<0.05)$. 


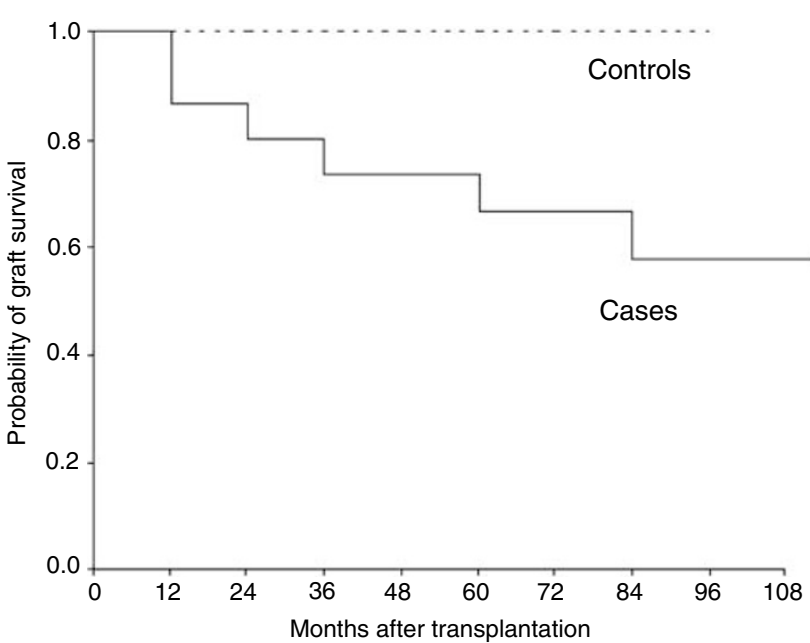

Figure 3 Kaplan-Meier analysis of graft survival in group I (cases) and group 2 (controls) patients. The estimated 1-, 5- and 8-year cumulative survival rates in group I were 80, 66 and $57 \%$, respectively, while in group II the 8-year cumulative survival rate was $100 \%$. There was a significant difference between the rate of graft survival among the patients of the two groups (Wilcoxon test

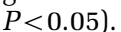

\section{Evaluation of Clinical Data and Outcome}

Although rejections in both groups of patients were early, the timing of rejections in group I was significantly later (mean $85.5 \pm 100.1$ days) than that observed in group II (mean $27.2 \pm 41.8$ days) $(P<0.05)$. The number of rejections in group I $(2 \pm 1.1)$ was significantly higher than that observed in group II $(1.3 \pm 0.5)(P<0.05)$. In group I, $7 / 15$ patients developed chronic/sclerosing allograft nephropathy vs $1 / 15$ patients in group II $(P<0.05)$. There was a significant difference between the graft survival rate among the patients of the two groups $(P<0.05)$ (Figure 3). In group I, estimated 1-, 5- and 8-year cumulative survival rates were 80,66 and $57 \%$, respectively. Graft loss occurred in six patients; it was due to chronic/sclerosing allograft nephropathy in five cases, and in one case to vascular acute rejection, following the withdrawal of the immunosuppressive therapy. In group II, the estimated 8-year cumulative survival rate was $100 \%$. There were no significant differences between group I and group II in terms of age $(38.1 \pm 10.1$ vs $37.4 \pm 13.0$ years), male/female ratio (8/7 vs 11/4), living/cadaveric donor ratio (3/15 vs $2 / 15)$, cold ischemia time ( $10 \pm 5$ vs $12 \pm 6 \mathrm{~h})$, HLA AB matching ( $2.7 \pm 0.97$ vs $2.5 \pm 0.96)$, occurrence of post-transplant tubular necrosis (3/15 vs 2/15), plasma levels of cyclosporin A $(277 \pm 85$ vs $326 \pm 96 \mathrm{ng} / \mathrm{ml}$ ), and mean percent increase of serum creatinine at the time of the biopsy (27 vs 19\%).

\section{Discussion}

In acute rejection biopsies of renal transplanted patients experiencing CMV or EBV disease in the year of the rejection, the number of plasma cells infiltrating the interstitium was higher than in acute rejection biopsies of patients without infections. In addition, there was a positive correlation between the number of infections and the number of plasma cells suggesting that a high number of plasma cells could be a sign of recurrent herpes virus infections. Reduced graft survival due to chronic allograft nephropathy was observed in the group of patients with infections, in line with the data in the literature suggesting that viral infections increase the risk of chronic allograft nephropathy. ${ }^{22-25}$ Our results are also in agreement with the observation that a high number of plasma cells in acute rejection biopsies is associated with a poor prognosis, due to the occurrence of chronic allograft nephropathy. ${ }^{47}$ How viral infections are involved in the development of chronic allograft nephropathy is not yet understood. We, as many other authors, ${ }^{4-9}$ have observed that the number of acute rejections in renal transplanted patients with infections is higher than in patients who do not undergo infections. The occurrence of acute rejections is known as a risk factor for development of chronic allograft nephropathy. ${ }^{48-50}$ Interestingly, the study by Humar et $a l^{24}$ showed only CMV disease associated with acute rejection to be a risk factor for the development of chronic allograft nephropathy. Moreover, in the presence of acute rejection, CMV had an additional detrimental effect that could not be completely accounted for by the severity of the rejection or by the type of therapy. In transplanted patients, CMV can trigger the formation of a variety of auto-antibodies. ${ }^{26-29}$ Among these, the anti-endothelial cell antibodies have been proposed to play a role in the development of antibody-mediated rejections both in heart and renal transplantation..$^{33-37}$ In our study, a diffuse and intense C4d deposition was present in five cases of the group of patients with viral infections but in none of the cases of group II. This suggests the presence of an antibody-mediated component in these rejections, although, unfortunately alloantibody assessment of patient serum samples obtained at the time of biopsy could not be performed. Three of the five patients with C4d positive rejections developed chronic allograft nephropathy followed by graft loss. It has been suggested that antibodymediated reactions contribute to the development of chronic allograft nephropathy ${ }^{40-42}$ and, in these cases, a more aggressive and specific antirejection therapy has been proposed. ${ }^{38,39}$ The absence of an appropriate therapy may have also contributed to the poor graft survival observed in group I. In a previous study, the occurrence of a bacterial or viral infection within 2 weeks before a renal biopsy was not significantly associated with C4d deposition. ${ }^{38}$ Whether an antibody-mediated component in acute rejection could have an additional detrimental effect on patients with herpesvirus infections needs to be further investigated. In agreement with a study showing the association of CMV infection with the 
development of acute rejections ${ }^{9}$ and with studies concerning acute rejections with a high number of plasma cells, ${ }^{47,51}$ we did not find evidence of CMV or EBV virus in the renal biopsies. This suggests that the viruses could have influenced the histology of the rejection in an indirect manner. CMV and EBV infections are associated with B lymphocyte activation and proliferation. ${ }^{10,11}$ In addition, in renal transplanted patients with CMV infection, an early transient increase in peripheral B lymphocyte levels has been documented. ${ }^{12} \mathrm{~A}$ soluble factor that could mediate, at least partially, these viral effects is IL10, a cytokine that induces B lymphocyte proliferation and differentiation in plasma cells. ${ }^{52}$ IL-10 has been detected in the plasma of renal transplanted patients with symptomatic or asymptomatic CMV infection. ${ }^{53}$ It is measurable in plasma in more than $50 \%$ of the patients with EBV-induced acute infectious mononucleosis and in chronic active EBV infection. ${ }^{54,55} \mathrm{EBV}$ induces the transcription of human IL-10 early and late during the viral productive cycle, and during latency. ${ }^{56-59}$ Moreover, both CMV and EBV encode and express biologically functional IL-10 homologous proteins. ${ }^{55,60-62}$ Thus, it is tempting to speculate that viral and human IL10 in plasma could affect the composition of inflammatory infiltrates in allografts in case of acute rejection.

In conclusion, our study confirms that renal transplanted patients experiencing viral diseases undergo chronic allograft nephropathy and reduced graft survival more frequently than patients without viral infection. We have shown for the first time that a high number of plasma cells in the interstitium and a C4d deposition in the peritubular capillaries of the graft may be present in patients experiencing viral infections. These data suggest that in some of these patients B lymphocytes may play a role in aggravating the injury caused by acute rejection.

\section{Acknowledgements}

We thank Professor Franco Ranelletti for helpful discussion and Elisabetta Baliello, Anna Saracino and Giuseppa Castriciani for their skilful technical assistance. This work was supported in part by MUIR funds, Rome and by $60 \%$ funds by University of Padua, Italy.

\section{References}

1 Wreghitt T, Gray J. Viral infection. In: Thirus S, Waldmann $\mathrm{H}$ (eds). Pathology and Immunology of Transplantation and Rejection. BlackWell Science: Oxford, UK, 2001, pp 446-469.

2 Fiala M, Payne JE, Berne TV, et al. Epidemiology of cytomegalovirus infection after transplantation and immunosuppression. J Infect Dis 1975;132:421-433.
3 Sia IG, Paya CV. Infectious complications following renal transplantation. Surg Clin North Am 1998;78: 95-112.

4 Briggs JD, Timbury MC, Paton AM, et al. Viral infection and renal transplant rejection. Br Med J 1972;4:520-522.

5 David DS, Millian SJ, Withsell JC, et al. Viral syndromes and renal homograft rejection. Ann Surg 1972;175:257-259.

6 Lopez C, Simmons RL, Mauer SM, et al. Association of renal allograft rejection with virus infections. Am J Med 1974;56:280-289.

7 von Willebrand E, Pettersson E, Ahonen H, et al. CMV infection, class II antigen expression, and human kidney allograft rejection. Transplantation 1986;42: 364-367.

8 Pouteil-Noble C, Ecochard R, Landrivon G, et al. Cytomegalovirus infection-an etiological factor for rejection? A prospective study in 242 renal transplant patients. Transplantation 1993;55:851-857.

9 Reinke P, Fietze E, Ode-Hakim S, et al. Late-acute renal allograft rejection and symptomless cytomegalovirus infection. Lancet 1994;344:1737-1738.

10 Price $\mathrm{P}$, Olver SD, Gibbons AE, et al. B-cell activation following murine cytomegalovirus infection: implications for autoimmunity. Immunology 1993;78:14-21.

11 Hutt-Fletcher LM, Balachandran N, Elkins MH. B cell activation by cytomegalovirus. J Exp Med 1983;158: 2171-2176.

12 Besancon-Watelet C, Kennel De March A, Renoult E, et al. Early increase of peripheral B cell levels in kidney transplant recipients with CMV infection or reactivation. Transplantation 2000;3:366-371.

13 Kaden J, Petersen S, Kaden K, et al. Epstein-Barr virus infection after kidney transplantation. Transplant Int 1998;11:S119-S124.

14 Karajannis MA, Hummel M, Anagnostopoulos I, et al. Strict lymphotropism of Epstein-Barr virus during acute infectious mononucleosis in nonimmunocompromised individuals. Blood 1997;8:2856-2862.

15 Ho M, Jaffe R, Miller G, et al. The frequency of Epstein-Barr virus infection and associated lymphoproliferative syndrome after transplantation and its manifestations in children. Transplantation 1988;45: 719-727.

16 Babel N, Schwarzmann F, Prang N, et al. Association between Epstein-Barr virus infection and late acute transplant rejection in long-term transplant patients. Transplantation 2001;72:736-739.

17 Grattan MT, Moreno-Cabral CE, Starnes VA, et al. Cytomegalovirus infection is associated with cardiac allograft rejection and atherosclerosis. JAMA 1989;261:35616.

18 McDonald K, Rector TS, Braulin EA, et al. Association of coronary artery disease in cardiac transplant recipients with cytomegalovirus infection. Am J Cardiol 1989;64:359-362.

19 Loebe M, Schuler S, Zais O, et al. Role of cytomegalovirus infection in the development of coronary artery disease in the transplanted heart. J Heart Transplant 1990;9:707-711.

20 Everett JP, Hershberger RE, Norman DJ, et al. Prolonged cytomegalovirus infection with viremia is associated with development of cardiac allograft vasculopathy. J Heart Lung Transplant 1992;11:S133-S137.

21 Shirali GS, Ni J, Cheninock RE, et al. Association of viral genome with graft loss in children after cardiac transplantation. N Engl J Med 2001;344:1498-1547. 
22 Lautenschlager I, Soots A, Krogerus L, et al. Timerelated effects of cytomegalovirus infection on the development of chronic renal allograft rejection in a rat model. Intervirology 1999;42:279-284.

23 Krogerus K, Soots A, Loginov R, et al. CMV accelerates tubular apoptosis in a model of chronic renal allograft rejection. Transplant Proc 2001;33:254.

24 Humar A, Gillingham KJ, Payne WD, et al. Association between cytomegalovirus disease and chronic rejection in kidney transplant recipients. Transplantation 1999;68:1879-1883.

25 Tong CY, Bakran A, Peiris JS, et al. The association of viral infection and chronic allograft nephropathy with graft dysfunction after renal transplantation. Transplantation 2002;74:576-578.

26 Hebart H, Einsele H, Klein R, et al. CMV infection after allogenic bone marrow transplantation is associated with the occurrence of various autoantibodies and monoclonal gammopathies. Br J Hematol 1996;95: 138-144.

27 Mengarelli M, Minotti C, Palumbo G, et al. High levels of antiphospholipid antibodies are associated with cytomegalovirus infection in unrelated bone marrow and cord blood allogenic stem cell transplatation. Br J Hematol 2000;108:126-131.

28 Naucler CS, Larsson S, Moller E. A novel mechanism for virus-induced autoimmunity in humans. Immunol Rev 1996;152:175-192.

29 Moller E, Soderberg-Naucler C, Sumitran-Karuppan S. Role of alloimmunity in clinical transplantation. Rev Immunogenet 1999;1:309-322.

30 Toyoda M, Galfayan K, Galera OA, et al. Cytomegalovirus infection induces anti-endothelial cell antibodies in cardiac and renal allograft recipients. Transplant Immunol 1997;5:104-111.

31 Toyoda M, Petrosian A, Jordan SC. Immunological characterization of anti-endothelial cell antibodies induced by cytomegalovirus infection. Transplantation 1999;9:1311-1318.

32 Varani S, Muratori L, De Ruvo N, et al. Autoantibody appearance in cytomegalovirus-infected liver transplant recipients: correlation with antigenemia. J Med Virol 2002;66:56-62.

33 Paul LC, Claas FH, van Es LA, et al. Accelerated rejection of a renal allograft associated with pretranplantation antibodies directed against donor antigens on endothelium and monocytes. $N$ Engl J Med 1979;300:1258-1260.

34 Jordan SC, Yap HK, Sakay RS, et al. Hyperacute allograft rejection mediated by anti-vascular endothelial cell antibodies with a negative monocyte crossmatch. Transplantation 1988;46:585-587.

35 Dunn MJ, Crisp SJ, Rose ML, et al. Anti-endothelial antibodies and coronary artery disease after cardiac transplantation. Lancet 1992;339:1566-1570.

36 Yard B, Spuyt-Gerritse M, Claas F, et al. The clinical significance of allospecific antibodies against endothelial cells detected with an antibody-dependent cellular cytotoxicity assay for vascular rejection and graft loss after renal transplantation. Transplantation 1993;55: 1287-1293.

37 Fredrich R, Toyoda M, Czer LS, et al. The clinical significance of antibodies to human vascular endothelial cells after cardiac transplantation. Transplantation 1999;67:385-391.

38 Nickeleit V, Zeiler M, Gudat F, et al. Detection of the complement degradation product $\mathrm{C} 4 \mathrm{~d}$ in renal allo- graft: diagnostic and therapeutic implications. J Am Soc Nephrol 2002;13:242-251.

39 Bohmig GA, Regele H, Exner M, et al. C4d-positive acute humoral renal rejection: effective treatment immunoadsorption. J Am Soc Nephrol 2001;11: 2482-2489.

40 Regele H, Exner M, Watschinger B, et al. Endothelial C4d deposition is associated with inferior kidney allograft outcome independently of cellular rejection. Nephrol Dial Transplant 2001;16:2058-2066.

41 Mauiyyedi S, Colvin RB. Humoral rejection in kidney transplantation: new concepts in diagnosis and treatment. Curr Opin Nephrol Hyper 2002;11: 609-618.

42 Mauiyyedi S, Crespo M, Collins AB, et al. Acute humoral rejection in kidney transplantation: II. Morphology, immunopathology, and pathologic classification. J Am Soc Nephrol 2002;13:779-787.

43 Racusen LC, Solez K, Colvin RB, et al. The Banff 97 working classification of renal allograft pathology. Kidney Int 1999;55:713-723.

44 The $\mathrm{TH}$, van der $\mathrm{Bij} \mathrm{W}$, von der Berg $\mathrm{AP}$, et al. Cytomegalovirus antigenemia. Rev Infect Dis 1990;12:5737-5744.

45 Gleaves CA, Hursh DA, Meyers JD. Detection of human cytomegalovirus in clinical specimens by centrifugation culture with a nonhuman cell line. J Clin Microbiol 1992;30:1045-1048.

46 Horwitz CA, Heule W, Heule G, et al. Long term serological follow-up of patients for Epstein-Barr virus after recovery from infectious mononucleosis. J Infect Dis 1985;151:1150-1153.

47 Charney DA, Nadasdy T, Wing-Hong A, et al. Plasma cell-rich acute renal allograft rejection. Transplantation 1999;68:791-797.

48 Matas AJ. Chronic rejection in renal transplant recipients - risk factors and correlates. Clin Transplant 1994;8:332-335.

49 Pirsch JD, Ploeg RJ, Gange S, et al. Determinants of graft survival after renal transplantation. Transplantation 1996;61:1581-1586.

50 Matas AJ. Risk factors for chronic rejection - a clinical perspective. Transplant Immunol 1998;6:1-11.

51 Meehan SM, Domer P, Josephson M, et al. The clinical and pathological implications of plasmacytic infiltrates in percutaneous renal allograft biopsies. Hum Pathol 2001;32:205-215.

52 Moore KW, de Waal Malefyt R, Coffman RL, et al. Interleukin-10 and interleukin-10 receptor. Annu Rev Immunol 2001;19:1230-1234.

53 Nordoy I, Muller F, Nordal KP, et al. The role of the tumor necrosis factor system and interleukin-10 during cytomegalovirus infection in renal transplant recipients. J Infect Dis 2000;181:51-57.

54 Taga $\mathrm{H}$, Taga $\mathrm{K}$, Wang $\mathrm{F}$, et al. Human and viral interleukin-10 in acute Epstein-Barr virus-induced infectious mononucleosis. J Infect Dis 1995;171 1347-1350.

55 Kanegane H, Wakiguchi H, Kanegane C, et al. Viral interleukin-10 in chronic active Epstein-Barr virus infection. J Infect Dis 1997;176:254-257.

56 Burdin N, Perrone C, Banchereau J, et al. Epstein-Barr virus transformation induces B lymphocytes to produce human interleukin 10. J Exp Med 1993;177: 295-304.

57 Nakagomi H, Dolcetti R, Bejarano MT, et al. The Epstein-Barr virus latent membrane protein-1 (LMP1) 
induces interleukin-10 production in Burkitt lymphoma lines. Int J Cancer 1994;57:240-244.

58 Kitagawa N, Goto M, Kurozumi K, et al. Epstein-Barr virus-encoded poly(A) (-) RNA supports Burkitt's lymphoma growth through interleukin-10 induction. EMBO J 2000;19:6742-6750.

59 Mahot S, Sergeant A, Drouet E, et al. A novel function for the Epstein-Barr virus transcription factor EB1/Zta: induction of transcription of the hIL-10 gene. J Gen Virol 2003;84:965-974.
60 Moore KW, O’Garra A, de Waal Malefyt R, et al. Interleukin-10. Annu Rev Immunol 1993;11: 165-190.

61 Kotenko SV, Saccani S, Izotova LS, et al. Human cytomegalovirus harbors its own unique IL-10 homolog (cmvIL-10). Proc Natl Acad Sci USA 2000;97: 1695-1700.

62 Spencer JV, Lockridge KM, Barry PA, et al. Potent immunosuppressive activities of cytomegalovirus-encoded interleukin-10. J Virol 2002;76:1285-1292. 